\title{
INTRODUCTION TO THIS ISSUE
}

The papers collected in this edition of The Legal Education Review were all presented at the second Feminist Legal Academics Workshop which was held at the Australian National University on February 23 and 24, 1995. The conference was attended by approximately 80 feminist academics and public servants from Australia, New Zealand, Canada, and Japan, and represented an extraordinarily successful gathering of feminists involved in the teaching and administration of the law. The large and enthusiastic attendance was clearly a symptom of the growing awareness among legal academics of the importance of gender-sensitive reform of the traditional law curriculum. ${ }^{1}$ The prevailing context, however, is also one in which traditional law teaching has been identified by the Federal Government as a major contributor to inequality before the law. Combined with current developments in legal pedagogy — including what has been called a "shifting paradigm" in thinking about the law ${ }^{2}$ — the conditions are conducive to major changes in legal education.

\section{A BRIEF HISTORY OF THE WORKSHOP}

The Australian Law Reform Commission's (ALRC) "Equality Reference” was established as part of the Federal Government's National Agenda for Women in early 1993. The discussion paper for the reference, ALRC Discussion Paper No 54, ${ }^{3}$ recognised, rather tentatively, that the male domination of the legal profession is one of the factors ensuring that women are not treated equally by the law. ${ }^{4}$ The claim made by the discussion paper is essentially that while in an ideal world the law would be made and administered by all, the reality is that women and other oppressed groups do not have equal access to legal careers, and that this is one of the reasons for discrimination by the law and legal institutions. The paper goes on to state that traditional legal education presents many obstacles to women wishing to pursue legal careers:

Although there are now almost equal numbers of female and male law students, many women consider law school to be an environment determined by traditional male, hierarchical values in which they experience alienation and powerlessness. Law schools still provide few role models of women in senior academic positions. Some women students claim to be stigmatised if identifiably "feminist" in classes or seminars. While feminist jurisprudence has been incorporated into the teaching of mainstream subjects by some academics, most law schools still fail to include it among core teaching subjects like torts, criminal law or administrative law. It is more often included in the optional curriculum, where it is arguably marginalised and seen by students to be of less benefit. ${ }^{5}$

The Law Reform Commissioners for the "Equality Reference" included leading feminist legal academics Hilary Charlesworth, Reg Graycar, and Jenny Morgan. An interim report dealing with access to the legal system was produced early in 1994, and the two parts of the final report were released late in 1994. The final report gives a clear picture of the entrenched masculine values in legal education, stating that legal education is "both a source of and a solution to the inequality women experience before the law". 6

Shortly after the release of the interim report the Federal Government announced that $\$ 300000$ from the National Priority Reserve Fund would be made available to "produce gender-inclusive curriculum material for use in undergraduate law courses". 7 The resulting "Gender Issues in the Law Curriculum” project, administered by the Department of Employment Education and Training (DEET), sought consultants to develop materials in relation to three themes — work, violence, and citizenship.

The primary aim of this project is to ensure that law students are made aware of or at least gain an appreciation of, the inadequacy of existing legal principles and structures when considering the reality of women's lives. One way this can be achieved is by the development of high quality case materials, focussing on priority themes, and capable of adaptation and use by lecturers teaching core curricula areas ...8

Consultancies for the three themes were awarded to Reg Graycar and Jenny Morgan for Work and 
Violence, and to a group comprising Sandra Berns, Paula Baron, Marcia Neave and Beth Gaze for Citizenship. Work on each of the areas has continued rapidly throughout 1995, and it is expected that the resulting materials will be available early in 1996.

\section{THE WORKSHOP: GENDER IN THE LAW CURRICULUM}

In addition to the money made available to the consultants, DEET also made a one-off grant to the Feminist Legal Academics Workshop to hold a conference to explore gender issues in the law curriculum. The core organising group for the conference included Hilary Astor, Juliet Behrens, Deborah Cass, Hilary Charlesworth, Reg Graycar and Jenny Morgan.

The central aim of the conference was to look at the traditional law curriculum from the perspective of feminist teachers and, to some extent, students. It did not specifically focus on pedagogy, although several of the papers, including Mary Jane Mossman’s “Gender Issues in Teaching Method: Reflections on Shifting the Paradigm” and Nan Seuffert's "Feminist Epistemologies and a Law-in-Context Jurisprudence Course: A New Zealand Experience”, both of which are published here, did address pedagogical matters. The remaining papers were presented in three main sessions organised around the themes of work, violence and citizenship which are being addressed in the DEET project.

One aim of the conference was to hear from some of the feminists who have been actively attempting to raise gender awareness in their teaching, and the papers in this volume draw on the breadth and depth of ideas which were raised in the plenary sessions. However, the conference also served as a forum for feminists to meet and discuss our ideas and the problems which we encounter in teaching law: this aim was achieved through the extensive use of discussion groups focussed on the three conference themes. The discussion groups gave conference participants the opportunity to discuss feminist definitions of work, violence, and citizenship, as well as to explore ways in which these definitions can be brought into the law curriculum and teaching methods.

The current feminist context is one in which intersecting oppressions cannot be ignored, and although it was not necessarily implied by the conference themes, one issue which constantly recurred in both the plenary sessions and the discussion groups was that of the relationship between various axes of oppression: race, gender, class, sexuality. In particular, the relationship between race and gender was highlighted by several of the speakers. Outside the "formal” program, a comparatively numerous "lesbian caucus” met to discuss new courses on law and sexuality, and other issues facing lesbian and gay academics and students.

\section{FEMINISM IN THE LAW CLASSROOM}

Themes: Work, Violence, Citizenship, below, will describe in more detail those papers published here which focus specifically on the three themes. Two of the papers, however, those by Mary Jane Mossman and Nan Seuffert stand alone in that they do not concentrate on any one of the themes, but rather provide a detailed overview of certain crucial aspects of the feminist theoretical context in legal education.

In "Gender Issues in Teaching Methods” Mary Jane Mossman focuses on the different relations of power in teaching environments which influence classroom dynamics, and inform students' perceptions of various teaching styles adopted by female and feminist teachers. She describes the situation as one which characterises the feminist position more generally — opening up huge "possibilities" while being fraught with the "pain" and dangers of confronting a very resistant tradition. In the context of teaching, that tradition rests on an inbuilt notion that knowledge is "objective” and that both teachers and students are ungendered and undifferentiated by other factors relevant to the learning environment. The context for the traditional assumption, of course, was one in which both teachers and students were largely male, and so it is not surprising that stereotypically masculine characteristics and preferences were ascribed to this "neutral" person. Mossman explores the implications, and possibilities, for teaching which flow from the feminist recognition that knowledge is not objective and that subjects are gendered. She also describes the pain associated with adopting non-traditional teaching philosophies and methods. One aspect of Mossman's analysis which was of particular interest to conference participants was her description of research which has been conducted in North America into the gendered nature of student responses to evaluation of teaching. 
The question of epistemology, or the nature of knowledge, is taken up more specifically by Nan Seuffert in her contribution. Seuffert reflects critically on feminist theories of knowledge, concentrating on Donna Harraway's re-evaluation of objectivity as a perspective in which the subject acknowledges their partial view. Using Haraway, Seuffert reconsiders standpoint epistemology, a theory of knowledge based on the idea that the oppressed understand more about the nature of the oppression than do their oppressors. In the second part of her paper Seuffert describes some of the ways in which an understanding of feminist epistemology has influenced a law-in-context jurisprudence course which is taught at the University of Waikato School of Law. Seuffert's article concludes with a consideration of some of the implications of feminist epistemological arguments for teaching.

\section{THEMES: WORK, VIOLENCE, CITIZENSHIP}

The three themes selected for the DEET project and the conference reflect the major areas of concern for women in their relationship with the legal system. They are not intended to be definitive of every available experience of law: rather, each theme represents a concentration of areas where women's oppression is most evident. The intention of such a approach is to illustrate that the manifestations of discrimination cut across traditional legal boundaries: violence against women is an issue for the law of torts as well as for the more obvious criminal law.

In addition to these broad areas, this collection of papers has a number of key themes. They include the role of critical feminist scholarship in exposing the socially constructed, contestable, nature of law and legal categories; the importance of challenging law's claim to neutrality and objectivity; and the centrality of contextualising law teaching, and of challenging and crossing interdisciplinary boundaries to draw on the social sciences, philosophy, economics, and literature in developing a gender-inclusive law curriculum. These themes are developed around the three broad subject areas identified in the DEET project.

Unfortunately not all of the papers presented at the conference are published here. However, in the following outline we have attempted to acknowledge the contributions made by all those who made presentations.

\section{Work}

The work theme cuts across several traditional areas of law. Larissa Behrendt explores the potential for the inclusion of the experience of Aboriginal women in the law school curriculum, looking in particular at issues of Aboriginal women's labour in post-invasion society. She highlights the importance of dealing with the intersections of "otherness" - of race, and gender, and sexual orientation and religious belief — and challenges feminist critiques of law which do not take account of diversity. Larissa Behrendt addresses some problems with integrating Aboriginal women's work into the law curriculum. These include dealing with the issue of complicity of non-Aboriginal people (including women) in the oppression of Aboriginal women - an issue whenever intersectionality is addressed - and the lack of written source materials, given the oral nature of the Aboriginal tradition. She encourages teachers to establish links with the Aboriginal community, inviting participation through, for example, presentation of oral history.

Both Laura Bennett and Rosemary Owens take Labour Law as their focus, and consider issues of curriculum and method. Laura Bennett challenges the usefulness of traditional case analysis methods in this area, arguing that Labour Law has to be put into its economic, industrial and social context if its gendered nature, and its implications for women are to be understood. This means examining the complex intersections of gender with class, age, workforce status and race, and moving beyond an analysis based primarily on notions of patriarchy an analysis which she argues does not properly reflect the experience, in particular, of working-class women.

Looking at course content, Laura Bennett draws attention to the exclusion or omission of issues of concern to many women workers from traditional Labour Law courses, which focus on industrial action rather than on award enforcement, and in courses on Occupational Health and Safety which emphasise legal rights but provide little analysis of the role of regulatory agencies, which may be more significant for employees in weaker industrial positions such as casual employees. Rosemary Owens highlights the focus of Labour Law on paid work, and the implications this has for legal characterisations of the unpaid work 
expected of women. Women tend also to be the majority of "atypical" workers - casual, part-time, temporary or home-based - a working pattern which can be seen as both advantageous to men, and one which reinforces the construction of women as primarily unpaid workers in the private sphere.

Rosemary Owens also emphasises the importance of interdisciplinary thinking, and of challenging these "understood" categories of paid-public and unpaid-private work. In addition she urges law teachers to look beyond traditional materials for their teaching resources. She argues for trying to gain access to decisionmaking in industrial commissions and in the increasingly private, and privatised, arena of conciliation hearings, and enterprise bargaining. She also looks to greater use of empirical work on the real working lives of women, for which lawyers should either develop skills in the social sciences or work collaboratively with others.

Peta Spender highlights the narrow doctrinal boundaries of traditional Corporations Law, within which women appear to be invisible. She offers an analysis locating women in business as well as corporations law, outlining women's differential participation in corporate structures. She distinguishes women's significant participation in small business structures where they are both managers and owners, their more limited participation as partners in small family companies, where they may have no active role in the management of the company but face personal liability in the event of insolvency, and their virtual nonparticipation in large corporations. She argues that this differential use of the corporate form reflects aspects of women's relationship with work. For example, drawing on the writings of Carol Gilligan and others, an argument is considered that women prefer to operate in the context of a narrative of relationships: they will therefore tend not to separate ownership and control, nor will they adopt limited liability structures which artificially distance individuals from the effects of their business enterprise. This potentially offers a significant challenge to the concept of separate legal personality. Whilst noting that the "different voice" analysis is clearly contentious, Peta Spender also observes that mainstream debates are also beginning to include the concept of corporate cultures based on nurturing rather than control.

\section{Violence}

The authors in this section explore the nature of violence, particularly violence against women. "Violence" is itself a category or construct, the very application of the term involving contested issues of inclusion and exclusion; violence is also fundamentally gendered. The feminist law teacher thus has an important role in exposing the extent and reality of violence in women's lives, "naming" the violence of, for instance, harassment in the workplace and oppressive power relations in the family and in the state, in contexts not always recognised as violent, and in examining also the gendered nature of violence and its implications for our understanding of masculinity.

At the conference, the topic was introduced by Hilary Astor, who highlighted the resistance to covering violence in the law curriculum, identifying the risk (or fear) that recognising the prevalence of violence could overwhelm the curriculum, together with a widespread unwillingness (in academia and the wider community) to take responsibility for violence, embodied in the well-known public/private dichotomy. Carol Thomas, from the Aboriginal Women's Legal and Advocacy Centre in Sydney, spoke about the enormous difficulties facing Aboriginal women seeking legal protection from violence. She stressed the need to work with Aboriginal women in a context that recognised the role of both gender and cultural factors in limiting access to legal redress. Unless the interconnections between racial and gendered violence are understood and made legally relevant, any change in the law's general approach to violence against women will have no impact on the lives of Aboriginal women.

The papers relating to violence published in this collection include those by Lisa Sarmas and Dianne Otto, who consider the concept of violence in the context of Equity Law and International Law respectively, areas not traditionally defined as raising significant issues of violence against women. Lisa Sarmas advocates close case analysis as one method of incorporating the examination of gendered violence into the equity and trusts curriculum. Using examples from the doctrines of undue influence, unconscionable dealing and breach of fiduciary duty, she demonstrates that critical, context-sensitive case analysis can reveal women's individual lived experiences of violence while also permitting examination of the legal narratives which construct particular understandings about women. Further, it can contextualise the development of doctrine, and expose the impact of doctrinal developments in defining what can be seen as 
state-sanctioned behaviour.

Dianne Otto highlights the ways in which international law condones and perpetuates violence against women, while at the same time purporting to promote world peace. She notes that the gendered effects of international law's authorisation of the use of force by states in certain circumstances are not treated as relevant legal considerations. The gendered outcomes of the activities condoned by international law are disguised by the use of gender-neutral terms, for instance the public/private distinction, liberal notions of equality, and universal standards based on male experience. Law teachers offering such critical analyses in International Law courses can therefore particularise "who is doing what to whom" - whose interests are served and who's subjugated by dominant legal discourses - and problematise ostensibly neutral legal "givens", emphasising the importance of situatedness and context in the construction of legal knowledge. In her paper, which is also published here, Julie Stubbs examines the challenges to the law curriculum — and to the law teacher - posed when violence against women is taken seriously as it is argued it must be, given its prevalence and pervasive effect on many aspects of women's lives. She advocates an interdisciplinary approach to teaching about violence, in particular looking at the potentially fruitful relationship of law and social science. She calls on teachers to develop a critical interdisciplinarity in their own methods and encourage it in those of their students. Her challenging paper identifies the benefits of such a perspective in dealing with, for example, the production of knowledge, the limited nature of the relationship between law's categories and women's lived experiences, and the evaluation of legal responses to (in this case) violence against women.

Julie Stubbs also considers the personally confronting nature of the material to be taught, together with the challenge posed — for men and for women students - by the gendered character of violence, and discusses the implications for teaching methods. She outlines the potential difficulties of dealing with the intersections of gender with race, class and sexuality in the context of violence, and the concerns of feminists to highlight women's agency rather than presenting women as "naturally" victims.

\section{Citizenship}

"Citizenship" is currently a popular [fashionable] topic in legal scholarship — but what does it mean? The authors in this section emphasised the necessity for challenging the meaning(s) of "citizenship", in teaching International Law, Constitutional Law, Administrative Law and Migration Law. "The Citizen" has in practice been male, given the focus on activities in the public sphere: a key task for the feminist teacher is the exposure of the gendered, raced and classed nature of this central figure.

Judith Gardam introduced the session, identifying the resistance to feminist analyses of the notion of the State as international citizen, and pointing to the importance of trying to shift the emphasis in international law teaching to show the impact of this area of the law on individual women's lives. Her presentation was an insightful analysis of the concept of citizenship as it applies to different "bodies". As part of this session at the conference, Sandra Berns outlined some of the directions being taken by the DEET consultants undertaking the citizenship aspect of the project.

Among the papers published, Kim Rubenstein highlights the importance of teaching methods and curriculum which reclaim the "political contexts within which citizenship is exercised in public law'. She notes the lack of women's voices in Constitutional Law, suggesting a contextualised case-based approach for re-introducing into such courses certain excluded historical stories. The extensive body of feminist writings on the State can be drawn on in the teaching of Administrative Law and Migration Law. A critical teacher will also draw attention to the impact of public law practices on the disadvantaged and less powerful, and the issues raised for policy development by the intersections of race, class and gender.

Anne Orford calls for the development of "ethical" practices of teaching and research about international law, that is, "in ways that take account of how international lawyers are located in global networks of power". She proposes ways in which feminist teachers can challenge dominant conceptions of citizenship ("a discourse that is fundamentally about exclusion") and sovereignty, and can raise questions about the implications of citizenship in a global context in the international law curriculum. Her analysis requires the teacher, and student, to articulate their relative positions - positions of gender, of race, of class - and to take responsibility for the power relations thus exposed. Anne Orford discusses the potentially unsettling nature of such teaching, and looks at strategies for harnessing and dealing with this, to allow 
students to engage actively and productively with feminist and other critical material.

\section{CONCLUDING REMARKS}

As is hopefully illustrated by these introductory comments and the articles which follow, feminist legal scholarship is continuing its strong development across all areas of the law school curriculum. The Feminist Legal Academics Workshop of 1995 has clearly contributed to this development, not only by bringing together in one forum a broad range of scholarship, but by inspiring those of us working in the area to continue to think critically about all areas of law, and to question traditional curricula and teaching methods. It is hoped that the Feminist Legal Academics Workshop will continue to be a successful forum for feminist scholarship in Australia.

\section{Margaret Davies \\ Bronwyn Naylor \\ Anne Orford \\ Dianne Otto \\ Guest Editors}

1 The feminist movement in legal academia has clearly gathered momentum through the 1990s, no doubt partly as a result of the appearance of several groundbreaking Australian works in the area, such as R Graycar \& J Morgan, The Hidden Gender of Law (Sydney: Federation Press, 1990), J Scutt, Women and the Law (Sydney: Law Book Company, 1990) N Naffine, Law and the Sexes (Sydney: Allen and Unwin, 1990) and M Thornton ed, Public and Private: Feminist Legal Debates (Melbourne: Oxford University Press, 1995). Although much progress has been made in gaining acceptance of feminism as an intellectual pursuit, the mainstream curriculum is still one of the major sites of struggle for feminist academics in both new and old law schools.

2 See M Le Brun \& R Johnstone, The Quiet (R)evolution: Improving Student Learning in Law (Sydney: Law Book Company, 1994) 26-29.

3 Australian Law Reform Commission, Equality Before the Law, (Discussion Paper 54) (Canberra: AGE, 1993), was followed by Australian Law Reform Commission, Equality Before the Law: Women's Access to the Legal System (Report No 67 - Interim) (Canberra: AGPS, 1994); Australian Law Reform Commission, Equality Before the Law: Women's Equality (Report No 69 Part I) (Canberra: AGPS, 1994); Australian Law Reform Commission, Equality Before the Law: Justice for Women (Report No 69 Part 11) (Canberra: AGPS, 1994).

4 ALRC DP 54,68.

5 Id at 69.

6 ALRC Report No 69 Part 11, supra note 3, at 134.

7 Consultancy Brief, DEET, 1 (1994).

8 Id at 2. 